[9] Roascio-Albistur, A., Gámbaro, A. (2018). Consumer perception of a non-traditional market on sous-vide dishes. International Journal of Gastronomy and Food Science, 11, 20-24. doi: https:/doi.org/ 10.1016/j.ijgfs.2017.10.002

[10] Jeong, K., O, H., Shin, S. Y., Kim, Y.-S. (2018). Effects of sous-vide method at different temperatures, times and vacuum degrees on the quality, structural, and microbiological properties of pork ham. Meat Science, 143, 1-7. doi: https://doi.org/10.1016/j.meatsci.2018.04.010

[11] Zonin, V. G. (2006). Sovremennoe proizvodstvo kolbasnyh i solenokopchenyh izdeliy. SanktPeterburg: Professiya, 224.

[12] Verboloz, E. I., Romanchikov, S. A. (2017). Features of the low-temperature heat treatment of meat products in a combi steamer with the imposition of ultrasonic vibrations. Proceedings of the Voronezh State University of Engineering Technologies, 79 (3), 35-41. doi: https://doi.org/10.20914/2310-1202-2017-3-35-41

[13] Pech' tomleniya, goryachego i holodnogo kopcheniya, hraneniya. Available at: http:// www.istoma.com

[14] Innovacionnye tekhnologii v proizvodstve kulinarnoy produkcii (2014). Sankt-Peterburg, 80.

[15] Zahorulko, O. Ye., Zahorulko, A. M. (2016). Pat. No. 108041 UA. Hnuchkyi plivkovyi rezystyvnyi elektronahrivach vyprominiuiuchoho typu. No. u201600827; declareted: 02.02.2016; published: 24.06.2016, Bul. No. 12. Available at: http://uapatents.com/5-108041-gnuchkijj-plivkovijj-rezistivnijjelektronagrivach-viprominyuyuchogo-tipu.html

[16] Kiptelaya, L., Zahorulko, A., Zagorulko, A., Liashenko, B. (2017). Improvement of IR emitter to create non-reflector dryer for plant raw materials. Technology Audit and Production Reserves, 2 (3 (34)), 17-22. doi: https://doi.org/10.15587/2312-8372.2017.98068

[17] Kontrol'no-izmeritel'nye pribory i sredstva avtomatizacii OVEN.

\title{
INVESTIGATION OF THE EXPEDIENCE OF MODIFICATION OF THE CARBOHYDRATE COMPOSITION OF RICE FLOUR IN THE TECHNOLOGY OF GLUTEN-FREE BREAD
}

\author{
Iryna Medvid \\ Department of Hotel and Restaurant Business \\ National University of Food Technologies \\ 68 Volodymyrska str., Kyiv, Ukraine, 01601 \\ medvidrina@gmail.com \\ Viktor Dotsenko \\ Department of Hotel and Restaurant Business \\ National University of Food Technologies \\ 68 Volodymyrska str., Kyiv, Ukraine, 01601 \\ dotsvf@gmail.com \\ Olena Shydlovska \\ Department of Hotel and Restaurant Business \\ National University of Food Technologies \\ 68 Volodymyrska str., Kyiv, Ukraine, 01601 \\ elena_shydlovska@ukr.net \\ Tetiana Ishchenko \\ Department of Hotel and Restaurant Business \\ National University of Food Technologies \\ 68 Volodymyrska str., Kyiv, Ukraine, 01601 \\ ichenkotat@gmail.com
}




\begin{abstract}
The research considers a possibility of using modification of the carbohydrate composition of rice flour in the technology of bread of the special destination for celiachia.

There has been conducted an analysis of the condition of the carbohydrate-amylase complex of rice flour. Revealed regularities have demonstrated that this flour has an unessential amylolytic activity that negatively influences the course of microbiological processes in gluten-free dough and quality parameters of ready products.

The aim of the research was to develop arrangements as to accumulation of sugars in dough at the expanse of own reserves of rice bread for providing the necessary intensity of rice dough fermentation by using enzymes of the amylolytic effect. It is a precondition for improving structural-mechanical and organoleptic properties of gluten-free rice bread. At the same time accumulation of products of incomplete hydrolysis of flour starch in the process of its fermentative modification - dextrins will favor deceleration of ready products staling.

There has been established the influence of $\alpha$-amylase of the fungal origin and glucoamylase on accumulation of sugars at hydrolysis of rice flour starch. It has been studied, that dosage of $\alpha$-amylase in amount $0,005 \%$ and glucoamylase $-0,03 \%$ of a flour mass results in creating sugars in amount 5,5-6\%. There has been proved the effectiveness of using $\alpha$-amylase by accumulation of dextrins, in which composition the essential raise of the content of low-molecular ones - archo- and maltodextrins has been determined.

Based on the conducted studies, it has been determined, that hydrolysis products of rice flour starch are created as a result of its fermentative modification by $\alpha$-amylase and glycoamylase that is testified by the increase of gas-creation and acid-accumulation.

There has been observed the positive influence of using modification of the carbohydrate composition of flour in the technology of rice bread on the specific volume, porosity structure and flexible-elastic properties of crumb of ready products.

It has been established, that realization of hydrolysis of flour starch at producing rice bread favors prolongation of its fresh storage term as a result of raising the amount of dextrins, created under the effect of $\alpha$-amylase.
\end{abstract}

Keywords: celiachia, gluten-free bread, rice flour, $\alpha$-amylase, glycoamylase.

DOI: $10.21303 / 2504-5695.2019 .00833$

(C) Iryna Medvid, Viktor Dotsenko, Olena Shydlovska, Tetiana Ishchenko

\title{
1. Introduction
}

The problem of improving the food structure, quality and safety of food products as a base of human life activity is today one of most important [1]. Taking into account the growth of the number of genetic and allergic diseases, special dietic food gains the high popularity. One of diseases that need correction of a food ration is celiachia, developed as a response to gluten consumption - specific proteins (gliadin and glutenin) of wheat, rye, barley and triticale. Despite great successes, achieved in understanding pathogenesis of gluten-depending diseases, a single effective method of treatment is the complete refusal of products, containing gluten [2], that is observance of gluten-free diet.

Among gluten-free food products, it is most problematic to produce bread, because just gliadin and glutenin are responsible for structure creation of crumb and volume of products. That is why an important technological task is to produce high-quality bread of gluten-free ingredients, because the absence of gluten results in increasing the gas-retaining ability of dough and structure formation [3].

\section{Review of the problem state}

For producing gluten-free bread products, processing products of such cultures as rice, buckwheat, corn, millet, sorgo, amaranth are allowed to use. In small amounts there are used processing products of leguminous (lupine, soya, haricot bean, pea) and oil (flax, sunflower) cultures [4].

Rice flour is promising for patients with celiachia, because it has neutral taste and hypoallergenic properties, white color, high assimilability, contains sodium, potassium, phosphorus, magnesium, vitamins $\mathrm{B}_{1}, \mathrm{~B}_{2}$ and $\mathrm{PP}[5,6]$. Its use in bakery is limited because of the impossibility to create dough with necessary structural-mechanical properties. The analysis of literary sources testifies that for improving the quality of rice flour bread, there are used hydrocolloids (xanthan and guar gum, carboxymethyl cellulose). At that a recipe of bakery products is added with starch (corn, potato, tapioca or their mixture) in amount $50 \ldots 90 \%$ of a mass of powdery raw materials. It gives a possibility to get bread with better specific volume and porosity structure of crumb [5, 7], but results in the essential decrease of its food value. 
The chemical composition of rice flour is characterized by the high starch content $(75 \ldots 82 \%)$ and small amount of mono- and disaccharides $(0,6 \ldots 0,7 \%)$. As it is known, just sugars play an important role in providing the necessary intensity of the fermentation process in dough, because they are a source of nutrition for yeast-saccharomycetes and sour-milk bacteria. That is why the research grounds the expedience of the additional introduction of saccharose [8] that results in the increase of a total volume of emitted carbonic gas. Data as to the improvement of the quality of bakery products of rice flour are absent, that conditions the research in this direction.

An urgent direction in the technology of producing bakery products for patients with celiachia is using methods that allow to modify properties of main chemical components of gluten-free flour by enzymes [9]. Today studies in the sphere of improving the bread quality using enzymes of the amylolytic effect that hydrolyze flour starch as a result of which the content of fermented sugars in bread increases develop actively [10,11]. Rice flour is a promising raw material for modifying its carbohydrate composition using these preparations. As far as rice flour is characterized by the high content of starch, it is possible to increase an amount of mono- and disaccharides in dough at the expanse of its own reserves. Based on it, it is expedient to establish a possibility of improving the rice bread quality by using enzymatic modification of starch by enzymes with amylolytic activity.

For this study, there has been chosen $\alpha$-amylase of the fungal origin and glycoamylase. Thus, $\alpha$-amylase spontaneously hydrolyzes $\alpha$-1,4-glucoside connections in an amylase molecule, in which result maltose and dextrins form. Glucoamylase is also able to catalyze the hydrolytic decomposition of $\alpha$-1,6-glucoside connections of spread chains of amylopectin of starch creating glucose [12].

The aim of the studies is the scientific substantiation of the possibility of using modification of the carbohydrate composition of rice flour for accumulating sugars using enzymes of the amylolytic effect in the technology of gluten-free bread. It favors activation of the process of alcohol fermentation in dough as a result of increasing an amount of mono- and disaccharides, that allows to improve the specific volume of products, porosity of crumb and organoleptic properties. At the same time formation of dextrins in the process of starch hydrolysis is a precondition of improving flexible-elastic properties of gluten-free bread and prolonging its storage term.

The following tasks were formulated for achieving the set aim:

- to study the condition of the carbohydrate-amylase complex of rice flour;

- to determine the influence of $\alpha$-amylase and glucoamylase on a change of the carbohydrate composition of rice flour;

- to establish the influence of enzymes on quality parameters of gluten-free bread and preservation of its freshness.

\section{Materials and Methods}

Rice flour with the following characteristics has been used as a main raw material for producing bread: mass share of moisture $-11 \%$, protein content $-8 \%$, fats $-1 \%$, mono- and disaccharides $-0,7 \%$, starch $-80,3 \%$.

For providing hydrolysis of rice flour starch, there has been used fungal $\alpha$-amylase with amylolytic activity $5000 \mathrm{SKB} / \mathrm{g}$, with optimal $\mathrm{pH} 4,7$, temperature $37-40{ }^{\circ} \mathrm{C}$ (Mühlenchemie, Germany) and glycoamylase, which activity is $500 \mathrm{AMG} / \mathrm{g}$, optimal $\mathrm{pH} 3,0-5,5$, temperature $40-64^{\circ} \mathrm{C}$ (Germany).

The other raw materials have been also used at preparing bread: pressed bakery yeast ( $3 \%)$, kitchen salt (1,2\%) and lemon acid (0,065\%).

For estimating the carbohydrate-amylase complex of rice flour, there have been determined its sugar-creating ability, autolytic activity and falling number [13]. Although this flour is not used as a main raw material, parameters of the carbohydrate-amylase complex are not regulated for it that is why wheat flour of the highest sort has been used as a control.

The effectiveness of enzymatic modification of rice flour starch has been estimated by assimilation of products of its hydrolysis, namely sugars (in recalculation for maltose) and dextrins. The total content of sugars has been determined by the iodometric method, based on determining the amount of oxide copper before and after renewal of its solution by sugar. The content of dex- 
trins has been determined by their ability to precipitate at different ethyl alcohol concentrations in the solution. The starch content has been determined by the chlorine-calcium method, in which the saturated solution of calcium chloride has been used for transforming polysaccharide in the soluble state [13].

Research methods of the quality of dough semi-products and ready bakery ones are considered in detail in work [13].

The experimental research results have been processed using the standard program package Microsoft Office (MS Excel 2010).

\section{Results}

Successfulness of the course of the technological process and provision of the high quality of bakery products considerably depend on the amount of sugars that are nutrition for yeast cells in dough, and also activity of the process of starch hydrolysis under the effect of own $\alpha$ - and $\beta$-amylase of flour with creating maltose. Rice flour has the essentially less content of mono- and disaccharides comparing with wheat flour of the highest sort, traditionally used for producing bread that may influence negatively its gas-creating ability. As it is known, own flour sugars are enough only for the beginning of fermentation. This further process is provided by depolymerization of starch under the effect of $\alpha$ - and $\beta$-amylase of flour, creating maltose. The activity of this process depends mainly on the state of flour starch, its pliability to the effect of enzymes, and also activity of flour amylase.

For determining the ability of rice flour to provide the process of dough ripening with sugars, the necessity to determine the activity of own $\alpha$ - and $\beta$-amylase in it appeared.

The activity of $\alpha$-amylase has been characterized by the falling number and autolytic activity by accumulation of water-soluble substances in the water-flour suspension at its heating (Fig. 1). The obtained data have been compared with wheat flour of the highest sort.

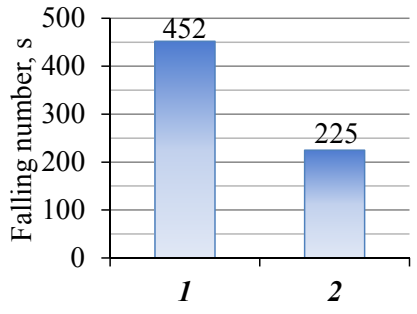

$a$

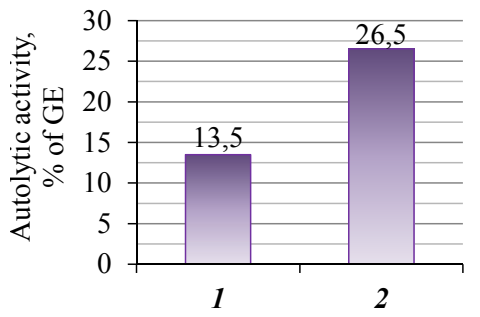

$b$

Fig. 1. $\alpha$-amylase activity: $a$ - falling number; $b$ - autolytic activity: 1 - rice flour, 2 - high-grade wheat flour

The analysis of the received data has demonstrated that rice flour is characterized by the decreased index of amylolytic activity by 49,1\% comparing with wheat flour of the highest sort. It is explained by more intensive amylolisis in the latter that favors the increase of an amount of water-soluble substances. At that it has been established, that the falling number of rice flour is higher by $50,2 \%$ comparing with wheat one.

The sugar-creating ability is conditioned by the effect of amyloytic enzymes on starch and depends on an amount and activity of first of all $\beta$-amylase and also a character and state of starch grains. An attack of rice starch by amylases is high that is conditioned by its grain sizes $5-6 \mathrm{mcm}$. There are the data that the starch pliability of a fine fraction of starch to the effect of $\beta$-amylase is 5 times higher than one of a big fraction [14]. Taking it into account, there has been studied the sugar-creating ability of rice flour for characterizing the activity of its own $\beta$-amylase. The results are presented on Fig. 2.

The results of determination of the sugar-creating ability have demonstrated that less amount of maltose by $49.3 \%$ accumulates in rice flour comparing with wheat one. The decrease of this index testifies that after fermenting own sugars of rice flour by yeast, they are not enough 
for further fermentation and provision of a reaction of melaninoidin creation, because not much maltose, created as a result of hydrolytic disintegration of flour starch under the effect of $\beta$-amylase accumulates in dough.

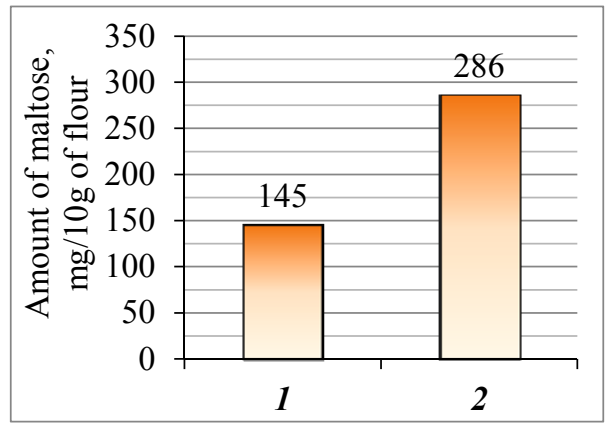

Fig. 2. Sugar-creating ability: 1 - rice flour, 2 - wheat flour of the highest sort

The obtained results correlate with literary data that testify to the insufficient activity of flour amylases [15]. That is why, for raising the amount of sugars in dough, necessary for providing the fermentation process, there has been offered to use fungal $\alpha$-amylase and glycoamylase in the technology of gluten-free bread. The optimal amount of enzymes has been determined by accumulation of mono- and disaccharides in the model dough system of rice flour without adding yeast, which moisture was $53 \%$ (Fig. 3). The duration of hydrolysis was 3 hours at environment temperature $40{ }^{\circ} \mathrm{C}$. At that $\alpha$-amylase was introduced in amount $0,002 \%, 0,005 \%$ and $0,007 \%$ to the flour mass, and glucoamylase $-0,03 \%, 0,04 \%$ and $0,05 \%$ to the flour mass. Yeast-free dough of rice flour without adding enzymes was used as a control sample.

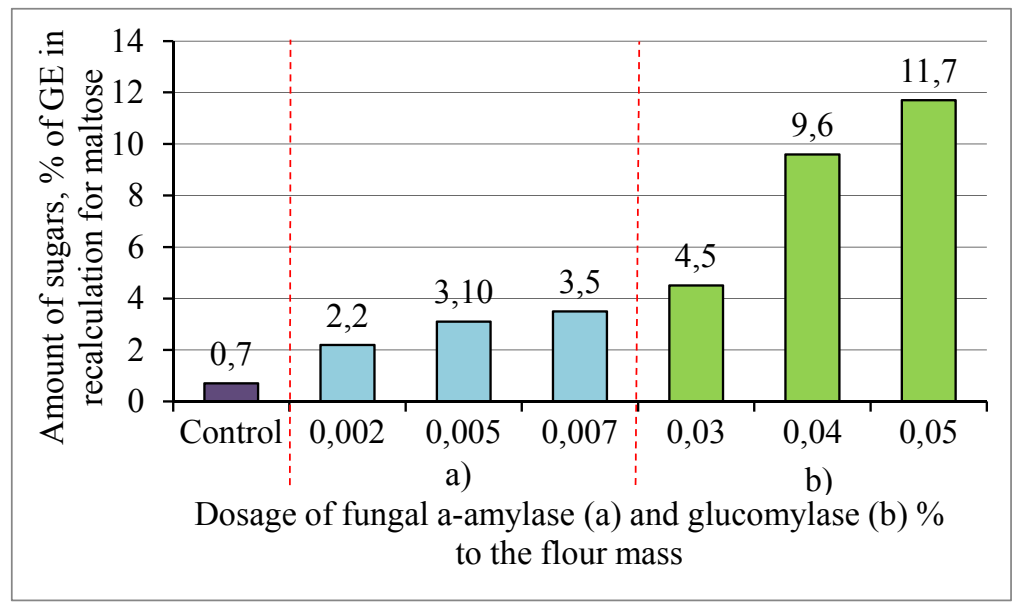

Fig. 3. Influence of enzymes on accumulation of sugars in rice dough

According to the research results, it has been established, that adding $\alpha$-amylase of the fungal origin results in increasing the content of sugars in dough in 3,2-5 times, comparing with a sample without using the enzymatic modification of starch (Fig. 3, a). At that the increase of dosage of $\alpha$-amylase more than $0,005 \%$ doesn't result in the essential growth of the amount of created products of starch hydrolysis.

The analysis of the results of the glucoamylase influence (Fig. 3, b) demonstrates that the share of saccharides, created in dough at its adding in amount $0,03 \%$ to the flour mass results in creation of $4,5 \%$ for GE of sugars that is 6,4 times more comparing with the control. The increase of glucoamylase dosage higher $0,03 \%$ favors the increase of the sugars content over $6 \%$, that is technologically undesirable, because the life activity of yeast cells in the process of alcohol fermentation of dough is inhibited at that. Based on the obtained results, the joint use of $\alpha$-amylase in 
amount $0,005 \%$ and glucoamylase $-0,03 \%$ to the flour mass that provides their synergetic effect is substantiated. As a result of it, the enzymatic modification of rice flour starch is more effective, and the amount of accumulated products of its hydrolysis, namely mono- and disaccharides, favors the intensification of dough fermentation.

For providing optimal conditions of the synchronous effect of $\alpha$-amylase and glycoamylase, there has been established an environment temperature as $40{ }^{\circ} \mathrm{C}$ and $\mathrm{pH}$ as 4,7 . For keeping the correspondent $\mathrm{pH}$ conditions, there was used lemon acid in amount $0,065 \%$ to the flour mass. As far as dough fermentation took place at $28-32{ }^{\circ} \mathrm{C}$, introduction of enzymes at the stage of dough batch is not enough effective. That is why for deeper rice flour starch hydrolysis and, as a result, accumulation of the necessary amount of sugars for the whole cycle of bread preparation, there has been experimentally established the necessity of conducting fermentative modification at temperature $40{ }^{\circ} \mathrm{C}$. For that there was prepared a mixture with $50 \%$ of the recipe amount of rice flour, lemon acid, enzymes and water, subjected to hydrolysis during 2 hours to accumulation of sugars in it as 5.5-6\%. Although the effectiveness of amylolytic enzymes on the substrate grows with increasing the environment humidity, the mass share of moisture in flour mixture is $65 \%$.

As it is known, depolymerization of starch molecules as a result of the $\alpha$-amylase effect is accompanied also by dextrins creation [12]. The excessive content of these compounds results in worsening flexible-elastic properties of bread crumb. In this connection there has been studied the dynamics of the enzymatic reaction by accumulation of amylo-, erythro-, malto- and archodextrins in time during 2 hours (Fig. 4).

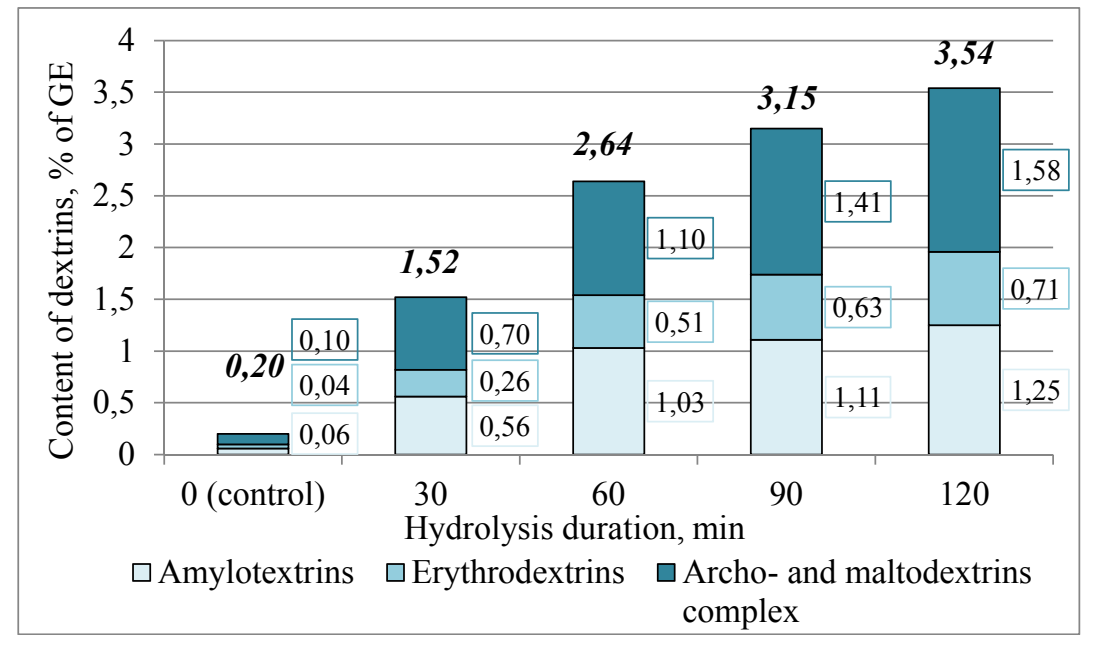

Fig. 4. Influence of $\alpha$-amylase on accumulation of dextrins

It has been established, that the use of fermentative modification of rice flour starch results in increasing the total amount of dextrins in 2 hours after hydrolysis by $94 \%$ comparing with the control. The obtained results may be explained by properties of rice starch, characterized with a high attack by amylolytic enzymes, and also low initial content of dextrins in flour $(0.2 \%$ of GE). At that the amount of low-molecular dextrins (archo- and maltodextrins) at the end of hydrolysis increases almost in 15 times. These compounds are able to increase the amount of bound water in bread crumb in times and to decelerate the process of retrogradation of starch.

Alongside with accumulating the necessary amount of mono- and disaccharides and dextrins, the content of starch proportionally decreases as a result of depolymerization of its molecules (Fig. 5).

The analysis of the obtained results has demonstrated that the content of rice starch for 2 hours of hydrolysis decreases by $27.3 \%$. It proves evidences about essential changes of the carbohydrate content of rice flour under the effect of $\alpha$-amylase and glucoamylase, connected with a break of $\alpha-1,4$ - and $\alpha-1,6$-glucoside connections. 


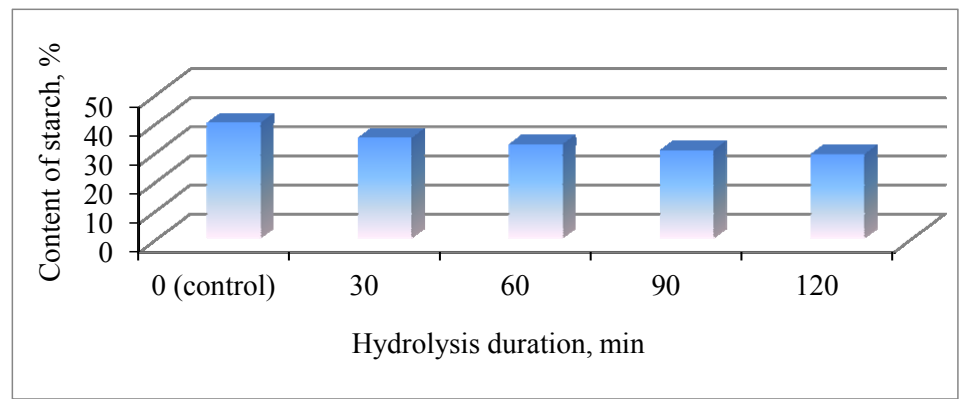

Fig. 5. Influence of enzymes on the starch content

Products of amylolisis (maltose, glucose), formed as a result of depolymerization of starch at using amylolytic enzymes, are a source of nutrition for yeast-saccharomycetes, that favors the improvement of the dough fermentation intensity. As a result of it, there are expected the improvement of the porosity structure and, so, the volume of gluten-free bread of rice flour. At further studies there has been determined the influence of using fermentative modification of flour starch on the course of the technological process and quality of ready products (Table 1). Dough was prepared based on a preliminarily prepared rice hydrolyzed semi-product with adding the yeast suspension, salt solution and the second part of flour according to the recipe. The calculated dough humidity was $53 \%$. A dough sample without using enzymes was a control. The fermentation duration was determined by time, when dough semi-products reached the maximal specific volume. It was experimentally established, that the period of dough ripening before baking is $20 \ldots 30$ min for the control, and $-45 \ldots 50 \mathrm{~min}$ for the dough sample with enzymes. The equal fermentation duration for both samples is not expedient, because they have a different carbohydrate content that influences the course of the technological process.

Table 1

Influence of enzymatic modification of rice flour starch on parameters of the technological process and bread quality

\begin{tabular}{lcc}
\hline \multicolumn{1}{c}{ Parameters } & $\begin{array}{c}\text { Control sample } \\
\text { (without supplements) }\end{array}$ & $\begin{array}{c}\text { Sample with fermentative } \\
\text { modification of flour starch }\end{array}$ \\
\hline Fermentation duration, min & Dough & 50 \\
Titrated acidity, degree: & 30 & 2,6 \\
- in. & 1,1 & 3,2 \\
- fin. & 1,4 & 330 \\
Gas-creating at fermentation, $\mathrm{cm}^{3} / 100 \mathrm{~g}$ of dough & 96 & 1,32 \\
Specific volume (at the end of fermentation), $\mathrm{cm}^{3 / \mathrm{g}}$ & 1,19 & 1,51 \\
\hline & Bread & 41,4 \\
\hline Specific volume, $\mathrm{cm}^{3} / \mathrm{g}$ & 1,31 & 2,8 \\
Porosity, $\%$ & 36,7 & 1,3 \\
Acidity, degree. & 1,3 & 2,6 \\
Crumbling, $\%$ & & 46 \\
in 3 hours & 2,5 & 59 \\
in 24 hours & 6,9 & \\
Total deformation of crumb, un. El. & & \\
in 3 hours & 48 & \\
in 24 hours & 34 & \\
\hline
\end{tabular}


According to the results of the studies, it has been established, that at using fermentative modification of flour starch in the technology of rice bread, there is observed the increase of dough acidity at the end of fermentation twice, comparing with the control sample. The increase of titrated acidity by 1,5 degrees comparing with the control is conditioned by introducing lemon acid for providing optimal $\mathrm{pH}$ conditions for the effect of $\alpha$-amylase and glucoamylase. At the same time, at the end of dough fermentation with enzymes, its acidity increases by 0,6 degrees, whereas one of the control sample - only by 0,3 degrees. It can be explained by accumulation of the big amount of carbonic acid in the dough semi-product at the expanse of dissolving carbon dioxide in the liquid phase of dough, and also organic acids, that testifies to the intensification of alcohol fermentation.

The obtained results of the influence of using amylolytic enzymes on gas-creation in dough testify to the increase of the amount of emitted carbon dioxide by 3,4\% comparing with the control. It is explained by introducing of the additional amount of mono- and disaccharides, created as a result of hydrolytic disintegration of starch, in dough.

Although the process of gas creation provides crumbling of dough semi-products, the increase of the amount of carbonic gas, emitted at their fermentation, positively influences the specific volume of dough and, accordingly, quality of ready bread. But the analysis of the obtained results demonstrates that the specific volume and porosity of gluten-free bread with using fermentative modification of flour starch grows only by $15,2 \%$ and $12,8 \%$ respectively, comparing with the control sample that doesn't result in the essential quality improvement of ready products. Such tendency is expected at using rice flour relating to gluten-free raw materials for bread production that results in the loss of carbon dioxide at ripening dough because of its low gas-retaining ability.

Bread freshness is one of main parameters of its quality and appropriateness to storage. According to the research results of changes of the crumb deformation degree, it has been established, that the use of the offered technology provides the increase of softness by $18 \%$ in 3 hours of storage, and after 24 hours - by $26 \%$. At that the increase of the penetration degree of bread with using fermentative modification of starch takes place less intensely than in the control sample. Better preservation of freshness of the studied sample of the rice bread comparing with the control one is proved also by the results of determining their crumbling. It is explained by accumulation of low-molecular dextrins as a result of amylolisis of flour starch under the effect of fungal $\alpha$-amylase that provides a longer storage term of freshness of ready products.

The analysis of organoleptic properties of gluten-free bread of rice flour using amylolytic enzymes has demonstrated that ready products have the even surface without breaks and cracks and also fine, even porosity of crumb. At the same time sugars, accumulated in the process of hydrolysis of flour starch, participate in Majar reaction at baking that conditions the light-brown coloration of crust and also pleasant taste and smell.

Thus, as a result of the conducted studies, it has been established, that the use of modification of the carbohydrate composition of rice flour in the bread technology intensifies gas-creation and acid accumulation in the process of dough ripening, in which result ready products are characterized with improved structural-mechanical quality parameters.

\section{Conclusions}

As a result of the conducted studies, it has been established, that rice flour has the insufficient activity of own $\alpha$ - and $\beta$-amylase. It has been proved, that introduction of fungal $\alpha$-amylase in amount $0,005 \%$ and glucomylase $-0,03 \%$ to the rice flour mass favors the accumulation of sugars, necessary for intensifying the course of the fermentation process in dough. The use of fermentative modification of the carbohydrate composition of rice flour in the technology of gluten-free bread favors creation of low-molecular dextrins that positively influence freshness preservation of ready products. It has been established, that the use of $\alpha$-amylase and glucoamylase at preparing rice bread intensifies gas creation and acid accumulation in the process of dough ripening and favors the improvement of flexible-elastic properties of crumb of ready products and their specific volume.

Taking into account the fact that the quality improvement of gluten-free bread if using amylolytic enzymes as improvers is mainly conditioned by activation of the fermenting microflora of dough, its technology needs arrangements as to the improvement of the gas-retaining ability. Fur- 
ther studies will be directed on searching structure creators of a moderate effect for more essential improvement of quality properties of the developed bread.

\section{References}

[1] Simakhina, H. O., Naumenko, N. V. (2016). Kharchuvannia yak osnovnyi chynnyk zberezhennia zdorovia naselennia. Problemy stareniya i dolgoletiya, 25 (2), 201-214.

[2] Pysarets, O. P., Biela, N. I., Hetman, I. A., Semenova, A. B. (2018). Dotsilnist zastosuvannia psylliumu u yakosti strukturoutvoriuvacha $\mathrm{v}$ tekhnolohiyi bezghliutenovykh khlibobulochnykh vyrobiv. Prodovolchi resursy, 10, 232-236.

[3] Hager, A.-S., Arendt, E. K. (2013). Influence of hydroxypropylmethylcellulose (HPMC), xanthan gum and their combination on loaf specific volume, crumb hardness and crumb grain characteristics of gluten-free breads based on rice, maize, teff and buckwheat. Food Hydrocolloids, 32 (1), 195-203. doi: https:// doi.org/10.1016/j.foodhyd.2012.12.021

[4] Drobot, V., Mykhonik, L., Gryschenko, A. (2017). The influence of structure forming food additives on the quality of gluten-free bread made from the mixture of rice and corn flour. Scientific Works of National University of Food Technologies, 23 (6), 169-175. doi: https://doi.org/10.24263/2225-2924-2017-23-6-21

[5] Kulinich, V. I., Havrysh, A. V., Dotsenko, V. F. (2013). Rysove boroshno - perspektyvna syrovyna dlia bezghliutenovykh produktiv. Naukovi pratsi Odeskoi natsionalnoi akademiyi kharchovykh tekhnolohiy, 1 (44), 175-178.

[6] Hatta, E., Matsumoto, K., Honda, Y. (2015). Bacillolysin, papain, and subtilisin improve the quality of gluten-free rice bread. Journal of Cereal Science, 61, 41-47. doi: https://doi.org/10.1016/j.jcs.2014.10.004

[7] Hryshchenko, A. M., Udvorheli, L. I., Mykhonik, L. A., Kovalevska, Ye. I. (2010). Doslidzhennia strukturno-mekhanichnykh vlastyvostei bezbilkovoho tista z kamediamy huaru i ksantanu. Kharchova nauka i tekhnolohiya, 1 (10), 63-65.

[8] Hryshchenko, A. M. (2011). Udoskonalennia tekhnolohiyi khliba z bezghliutenovoi syrovyny. Kyiv, 20.

[9] Renzetti, S., Dal Bello, F., Arendt, E. K. (2008). Microstructure, fundamental rheology and baking characteristics of batters and breads from different gluten-free flours treated with a microbial transglutaminase. Journal of Cereal Science, 48 (1), 33-45. doi: https://doi.org/10.1016/j.jcs.2007.07.011

[10] Goesaert, H., Slade, L., Levine, H., Delcour, J. A. (2009). Amylases and bread firming - an integrated view. Journal of Cereal Science, 50 (3), 345-352. doi: https://doi.org/10.1016/ j.jcs.2009.04.010

[11] Konsula, Z., Liakopoulou-Kyriakides, M. (2004). Hydrolysis of starches by the action of an $\alpha$-amylase from Bacillus subtilis. Process Biochemistry, 39 (11), 1745-1749. doi: https://doi.org/10.1016/ j.procbio.2003.07.003

[12] Popper, L. (2009). Fermentnaia obrabotka muki. Khleboprodukty, 6, 46-49.

[13] Drobot, V. Y., Yurchak, V. H., Bilyk, O. A. et. al. (2015). Tekhnokhimichnyi kontrol syrovyny ta khlibobulochnykh i makaronnykh vyrobiv. Kyiv: Kondor, 972.

[14] Arsynenko, N. O., Arsenieva, L. Yu. (2010). Tekhnolohichni vlastyvosti boroshniano-zernovoi sumishi zadanoho khimichnoho skladu. Naukovi pratsi Odeskoi natsionalnoi akademiyi kharchovykh tekhnolohiyi, 38 (1), 257-261.

[15] Krasina, I. B., Prudnikova, T. N., Ziuzko, A. S. (2008). Uglevodno-amilaznyi kompleks vtorichnykh produktov pererabotki risa-zerna. Izvestiya vuzov. Pishchevaia tekhnologiya, 2-3, 32-33. 